\title{
Changes in the Life Patterns of Families in the Nordic Countries
}

\author{
By ELINA HAAVIO-MANNILA and KYLLIKKI KARI
}

University of Helsinki

Department of Sociology

Changes in two major areas of social life, the family and work, have been produced over several decades by the complex interaction of many demographic, social, economic and technological forces. This article attempts to document some of these changes in four Nordic countries: Denmark, Finland, Norway and Sweden. The analysis is based on published statistical sources. It more or less covers the 20th century, from 1900 to around 1975. Due to the preliminary nature of this report, the deeper connections between family and work remain relatively implicit. But even from the descriptive data presented here it becomes evident that both the family and work have undergone profound changes during this century.

This report is the first one prepared by Finnish researchers for the comparative study on "Changes in the life patterns of families in Europe», which in 1979 was started by the European Coordination Center for Research and Documentation in the Social Sciences (Vienna Center) as a result of a Nordic initiative. The Finnish Academy is financing part of the study in Finland as well as paying some of the costs of a Nordic secretary coordinating the study at the Vienna Center.

In the first section we analyse one aspect of the socio-economic structure of the four Nordic countries. We study the structure of the adult male and female populations according to the degree and type of economic activity. The statistics on economic activity show how many people are registered as economically active. They do not indicate the amount of either paid or unpaid work in society. However, we can assume that at least those who are working in industry and services are paid for their work, and are operating in the market system. The classification of the agricultural population raises both conceptual and statistical problems, which are given only passing reference in this article.

The second part of the report describes population changes during this century. We now turn from the study of production to that of biological reproduction. In the third section we compare marriage rates, ages at first marriage and proportions of married persons in the Nordic countries. And finally, in the fourth part we look at the size of the household and family type. 


\section{Degree and Type of Economic Activity}

During this century the development of the degree and type of economic activity of the male population has been very similar in three of the four Nordic countries studied, that is in Denmark, Norway and Sweden. While in 1900 between $40 \%$ and $50 \%$ of men aged 15 and over were active in industry and services, the proportion had risen to almost $65 \%$ in 1960 . Only in Denmark did it still somewhat increase after that, but even there the increase stopped by 1970 .

The proportion of agricultural male population has in these three countries declined from about $45 \%$ in 1900 to less than ten per cent in 1975. At the beginning of the century, there were more men working in industry and construction (about $25 \%$ ) than in the service occupations $(12-22 \%$ ). At present more men are engaged in services than in industry and construction in these three countries (Table 1). These countries are thus now at the post-industrial stage of development.

Due to the longer time spent in education, and because of the longer life expectancy in retirement, the proportion of economically non-active men has increased from about $10 \%$ in $1900-1930$ to around $25 \%$ in 1975 . There are thus nowadays relatively fewer economically active men than there were in the near past. However, the economic activity of men in the middle of their productive age is still very high. It is at the two ends of the life cycle that men have stopped working for their living.

The industrialization process took place much later in Finland than in the other three countries. Not until 1940 did Finnish men reach the same level of economic activity in industry and services which Swedish men had reached in 1900. And the gap between Finland and the other Nordic countries has only slowly been diminishing. It is still considerable: the proportion of men working in secondary and tertiary industries is about ten percentage points lower than in the other countries studied. This is mostly accounted for by the higher proportion of men working in agriculture. The proportion of men engaged in agriculture first began to decline after the Second World War. The shift was very rapid in the $1960 \mathrm{~s}$, when the proportion of men in agriculture diminished from $32 \%$ to $17 \%$, and it continued at the same pace in the $1970 \mathrm{~s}$, being only $10 \%$ in 1975.

The process of moving into industry and services already seems to have reached its culmination among men. The increase in the proportion of men working in secondary and tertiary occupations stopped in Sweden in 1960, in Denmark, Finland and Norway in 1970. Even though young male students may increasingly live away from their parents' home, there already is and will be in the future an increasing number of (elderly) men staying at home as welfare or old age pensioners.

The movement of women into industrial and service occupations in Finland does not differ as much from that in the other Nordic countries as does the 
Table 1. Economic activity of men and women aged 15 and over in 19001975, per cent.

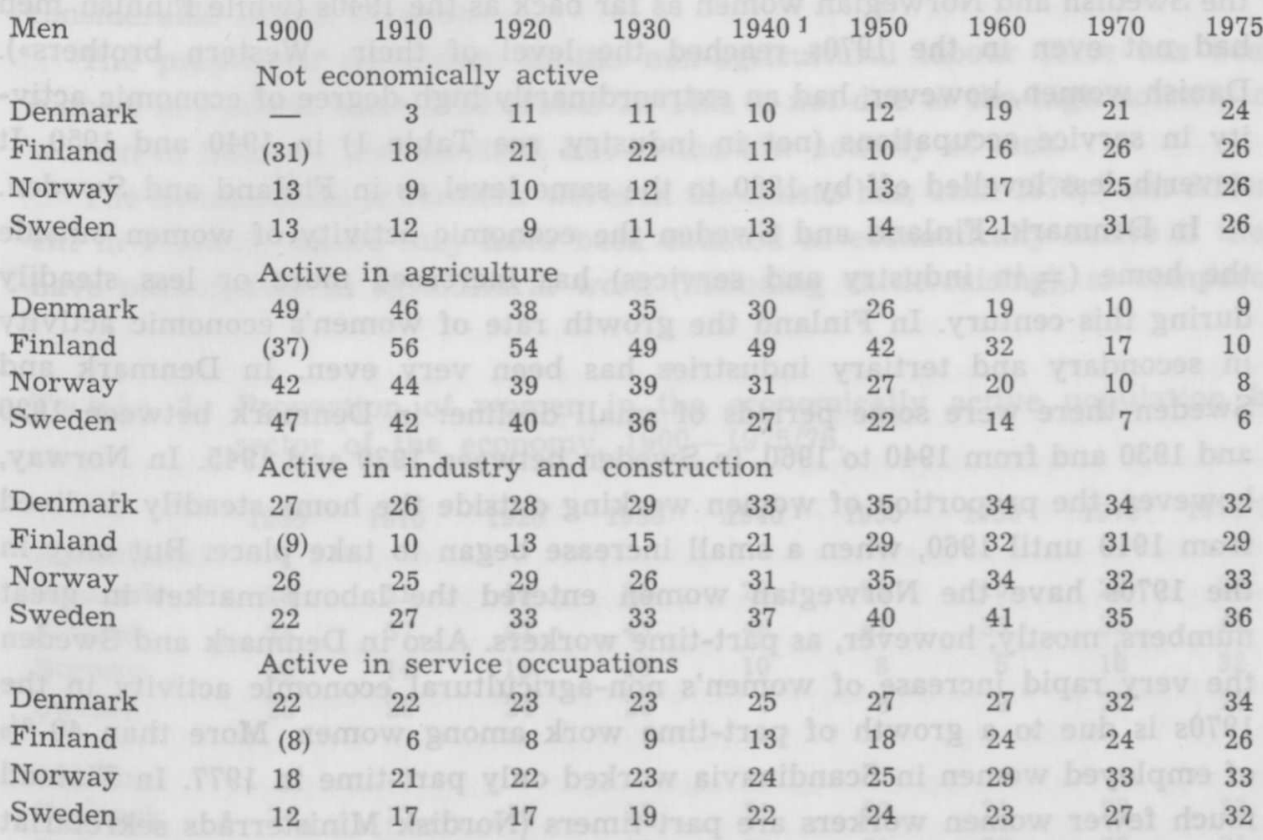

Women

Not economically active

\begin{tabular}{|c|c|c|c|c|c|c|c|c|}
\hline Denmark & 57 & 60 & 65 & 64 & 54 & 57 & 65 & 56 \\
\hline Finland & (74) & 55 & 48 & 48 & 39 & 47 & 51 & 52 \\
\hline vay & 63 & 66 & 68 & 70 & 72 & 74 & 76 & 72 \\
\hline & & & 64 & 62 & & 70 & & \\
\hline
\end{tabular}

Active in agriculture

$\begin{array}{lrrrrrrrrr}\text { Denmark } & 18 & 11 & 6 & 9 & 9 & 8 & 2 & 3 & 3 \\ \text { Finland } & (11) & 32 & 36 & 35 & 37 & 24 & 16 & 8 & 6 \\ \text { Norway } & 9 & 6 & 6 & 4 & 3 & 2 & 1 & 2 & 3 \\ \text { Sweden } & 19 & 13 & 12 & 10 & 2 & 2 & 1 & 2 & 2\end{array}$

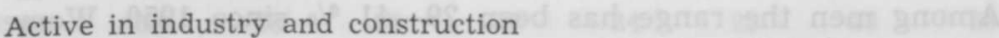

$\begin{array}{lcrrrrrrrr}\text { Denmark } & 8 & 7 & 6 & 5 & 8 & 10 & 9 & 10 & 9 \\ \text { Finland } & (2) & 3 & 8 & 5 & 8 & 11 & 11 & 12 & 12 \\ \text { Norway } & 9 & 7 & 7 & 6 & 6 & 7 & 5 & 5 & 7 \\ \text { Sweden } & 3 & 4 & 7 & 8 & 7 & 8 & 9 & 8 & 10 \\ & \text { Active in service } & \text { occupations } & & & & & \\ \text { Denmark } & 16 & 19 & 22 & 21 & 292 & 26 & 24 & 30 & 38 \\ \text { Finland } & (4) & 5 & 6 & 8 & 13 & 17 & 23 & 29 & 33 \\ \text { Norway } & 18 & 20 & 19 & 20 & 18 & 17 & 18 & 20 & 35 \\ \text { Sweden } & 7 & 11 & 16 & 20 & 19 & 20 & 22 & 28 & 42\end{array}$

1 Sweden 1945.

2 Domestic workers were from 1940 onwards included in the statistics.

Source: Mitchell 1975; International Labour Office, Year Books of Labour Statistics; United Nations, Demographical Yearbooks. 
movement of men. Even though Finnish women started later than their »Western sisters» to work in industry and services, they reached the level of the Swedish and Norwegian women as far back as the 1940s (while Finnish men had not even in the 1970 s reached the level of their "Western brothers»). Danish women, however, had an extraordinarily high degree of economic activity in service occupations (not in industry, see Table 1) in 1940 and 1950. It nevertheless levelled off by 1960 to the same level as in Finland and Sweden.

In Denmark, Finland and Sweden the economic activity of women outside the home ( $=$ in industry and services) has increased more or less steadily during this century. In Finland the growth rate of women's economic activity in secondary and tertiary industries has been very even. In Denmark and Sweden there were some periods of small decline: in Denmark between 1920 and 1930 and from 1940 to 1960, in Sweden between 1930 and 1945. In Norway, however, the proportion of women working outside the home steadily declined from 1910 until 1960, when a small increase began to take place. But only in the 1970 s have the Norwegian women entered the labour market in great numbers, mostly, however, as part-time workers. Also in Denmark and Sweden the very rapid increase of women's non-agricultural economic activity in the $1970 \mathrm{~s}$ is due to a growth of part-time work among women. More than $40 \%$ of employed women in Scandinavia worked only part-time in 1977. In Finland much fewer women workers are part-timers (Nordisk Ministerråds sekretariat $1979,114-115)$. The reason why the Norwegian development was so different from that in the other Nordic countries still remains to be studied. The intercountry differences are visible also in the non-agricultural economic activity of women in the four capitals. 1

Very few women have ever worked in industry and construction in the Nordic countries. The percentage of women aged 15 and over who are economically active in secondary industries has ranged between 3 and $12 \%$ throughout this century. Until the Second World War the inter-country differences were small. Since 1950 the order of the countries has been 1) Finland (11$12 \%), 2)$ Denmark $(9-10 \%)$, 3) Sweden (8-10\%) and 4) Norway $(5-7 \%)$. Among men the range has been $29-41 \%$ since 1950 . Women are thus in a clear minority among industrial workers - their proportion has ranged between 12 and $31 \%$, as Table 2 shows.

Due to the later economic development of Finland, the proportion of women in service occupations reached the Scandinavian level for the first time in 1960. At that time almost every fourth adult woman was working for pay in services in Denmark, Finland and Sweden whereas in Norway only $18 \%$ of women did so. By 1975 more than a third of all adult women in the Nordic countries were representatives of the post-industrial, service society. The proportion was even

1 In 1970 the proportion of women aged 16 and over economically active in nonagricultural occupations was $59 \%$ in Helsinki, $47 \%$ in Copenhagen, $46 \%$ in Stockholm and $37 \%$ in Oslo (includes only women working 1000 hours or more per year). Source: Statistical Yearbooks of the cities, NOS Folke-og boligtelling 1970 II. 
larger than among men. Thus in the Nordic countries more than half of all persons working in the service sector are women, and this has been so for a considerable length of time.

The proportion of women in the non-agricultural labour force has been highest in Finland since 1920 (Table 2). This is not due to the high activity of women in industry and services, but to the low activity of men.

The classification of farmers' wives in the census has, until 1970, been different in Finland, where they have been counted as economically active if they have participated in agricultural work (including cattle-raising), as compared

Table 2. Proportion of women in the economically active population by sector of the economy, $1900-1975 / 76$.

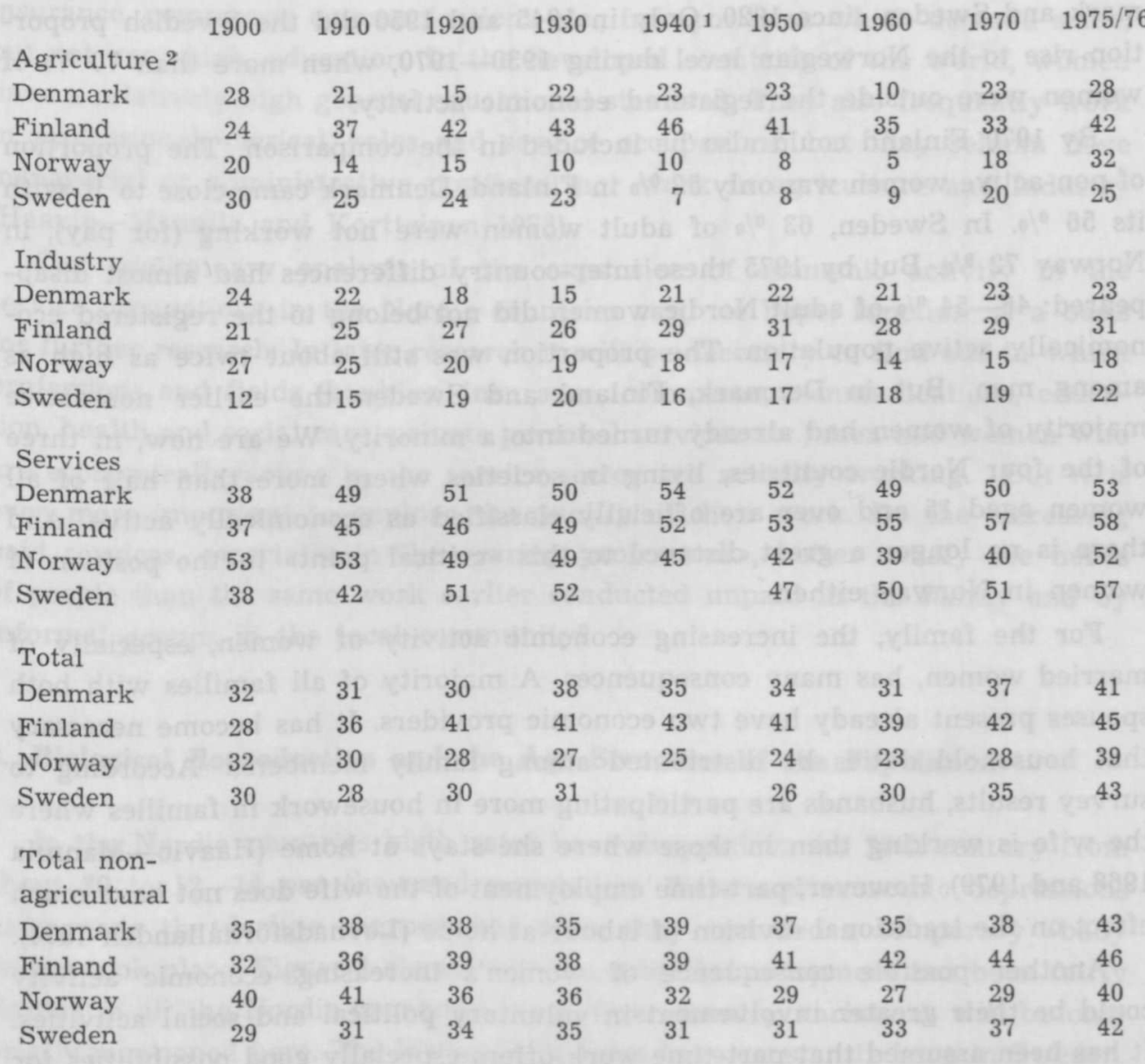

1 Norway 1946 and Sweden 1945.

2 The classification of farmers' wives as economically active has not been made in the same way in all countries - in Finland they have been included more often than in the other three countries.

Source: See Table 1. 
to Scandinavia, where they have mostly been omitted from the statistics on economic activity. Thus it is useless to compare Finland with the other Nordic countries. (In this case Finland can be easily compared with Eastern Europe). In Scandinavia the proportion of adult women included in the active agricultural population was, at the beginning of the 20th century, higher in Denmark and Sweden than in Norway. The decline was slowest in Denmark, where in $19608 \%$ of women were still classified as active in agriculture. In Norway and Sweden at that time they accounted for only $2 \%$.

Because of differences in the classification basis, it is also useless to compare the proportion of women not economically active in Finland and in Scandinavia before 1970. It is, however, interesting to see the differences between Norway on the one hand, and Denmark and Sweden on the other. In Norway, the proportion of economically non-active adult women has been higher than in Denmark and Sweden since 1920. Only in 1945 and 1950 did the Swedish proportion rise to the Norwegian level during $1930-1970$, when more than $70 \%$ of women were outside the registered economic activity.

By 1970 Finland could also be included in the comparison. The proportion of non-active women was only $52 \%$ in Finland. Denmark came close to it with its $56 \%$. In Sweden, $63 \%$ of adult women were not working (for pay), in Norway $72 \%$. But by 1975 these inter-country differences had almost disappeared: $46-54 \%$ of adult Nordic women did not belong to the registered economically active population. The proportion was still about twice as high as among men. But in Denmark, Finland and Sweden the earlier non-active majority of women had already turned into a minority. We are now, in three of the four Nordic countries, living in societies where more than half of all women aged 15 and over are officially classified as economically active. And there is no longer a great distance to this "critical point» in the position of women in Norway either.

For the family, the increasing economic activity of women, especially of married women, has many consequences. A majority of all families with both spouses present already have two economic providers. It has become necessary that household duties be distributed among family members. According to survey results, husbands are participating more in housework in families where the wife is working than in those where she stays at home (Haavio-Mannila 1968 and 1979). However, part-time employment of the wife does not have much effect on the traditional division of labour at home (Levnadsförhållanden 1974).

Another possible consequence of women's increasing economic activity could be their greater involvement in voluntary political and social activities. It has been assumed that part-time work offers especially good possibilities for this. However, in Sweden women working part-time participate less in voluntary civic activities than do those working full-time (Eduards 1977). This can be explained by referring to the type of Swedish women who select part-time work. They may be traditionally-oriented housewives who take a job just in order to fill the time available from their housework. They are thus not partic- 
ularly active in social pursuits outside the home. In Norway, however, where for a long time women have stayed at home, even part-time work can be considered emancipatory. That may explain the finding that part-times are particularly active in politics and voluntary organizations (Albrektsen 1977).

The increase in the economic activity of women has taken place mostly in the service sector of the economy. Unpaid caretaking work at home has changed into paid economic activity. In the welfare state many educational, health and social care services earlier more or less well provided by the family, or by informal groups in the local community, have increasingly become professionalized (Wadel 1977, see also Kolberg 1978). They have been taken over by the public sector. In this process many new jobs have been created. Women have been able and willing to enter them. In the privately-owned sector of the economy, too, women have been recruited into many paid jobs in banking, insurance, commerce, communications etc., into positions which demand some, but not very high, education. In the developed countries of the world, women have a relatively high general educational standard. They also frequently work in professional, clerical, sales and service occupations, but they seldom have managerial or administrative positions, nor work in agriculture and industry (Haavio-Mannila and Kortteinen 1978).

Our preliminary analysis of the expansion of economic activity in the service occupations in the Nordic countries can, we hope, function as a basis for further research. In later research it will be necessary to find out in which professions and fields (banking, insurance, commerce, communications, education, health and social care, private personal services etc.) men and women who are economically active in the service sector are actually working. But it is even more important to explore the quality of their work. Do the increasing paid services, especially in the "caring professions», better satisfy the needs of people than the same work earlier conducted unpaid in the family and by informal groups in the local community?

\section{Biological Reproduction and the Age Structure of the Population}

In the Nordic countries birth rates have dropped in the 20th century from about 30 to $12-14$ per thousand population. Wars and economic depressions have made the decline sharper, but after they occurred a temporary »baby boom» took place. Figure 1 shows that the overall development has been fairly similar in all the Nordic countries. Some inter-country variations will be only briefly mentioned here. The lowest birth rates have constantly been in Sweden. Finland had the highest rates until 1963. After that, until 1975, the Norwegians took the lead. Denmark had the next highest birth rates until 1948, when the Norwegian rate became higher than the Danish one.

Biological reproduction, in the sense of bringing new people into the world, has thus diminished numerically. However, most children nowadays stay alive, 
Figure 1. Crude birth rate, births per 1000 total population.

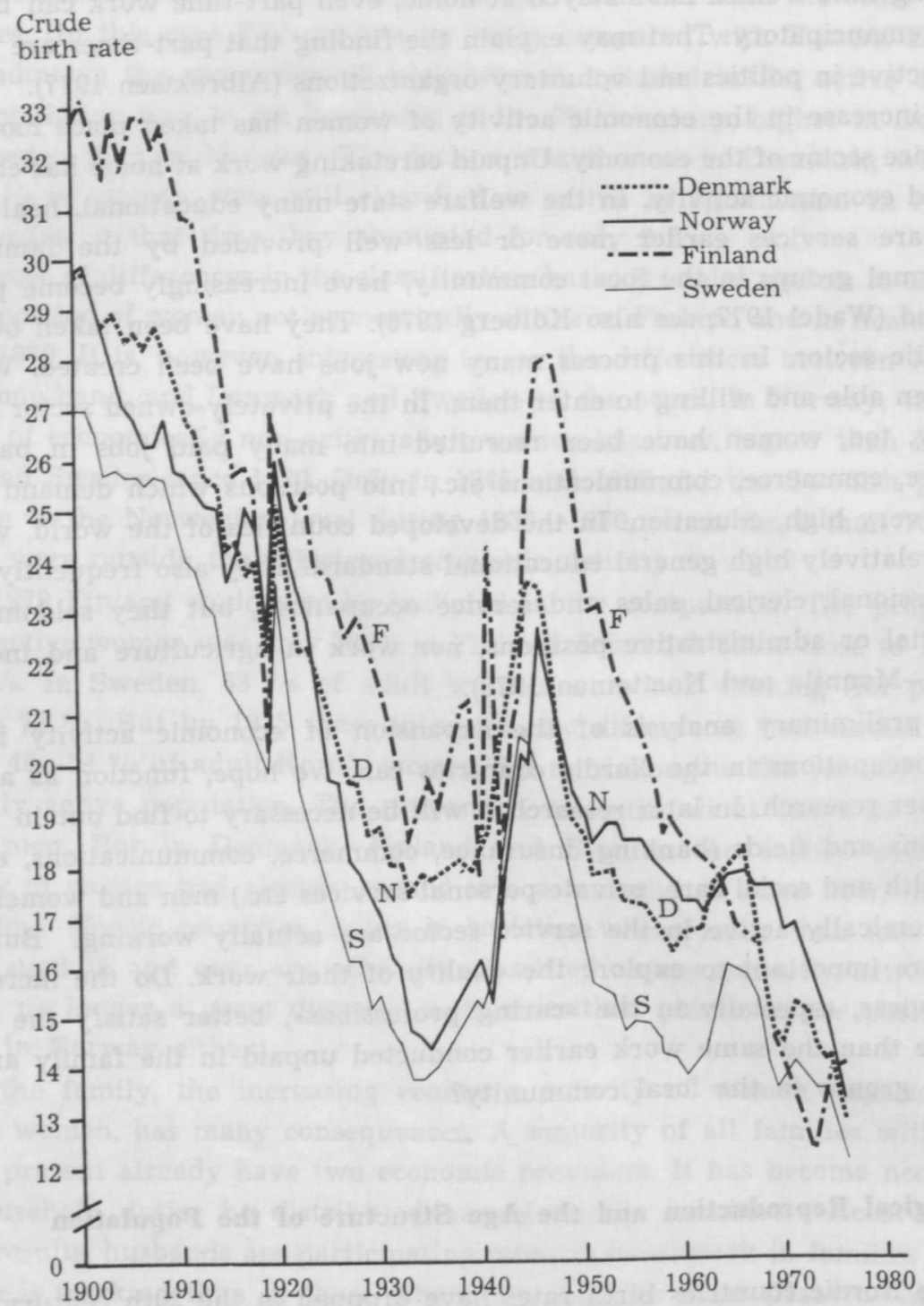

and have to be given primary socialization in the family. The most important change for the family in this connection is the shortening of the child-bearing period, which can be seen in the age-specific fertility rates (Figures 2 and 3 ). As the latest figures (Figure 2) show, most children are born before the mother is 30 years of age. The average age of the mother when the first child is born is $24-25$ years.

As a consequence of the lowering birth and death rates, the age structure of the population has changed. Figure 4 shows the percentages of children, 
Figure 2. Age-specific fertility rates in 1961-1970.

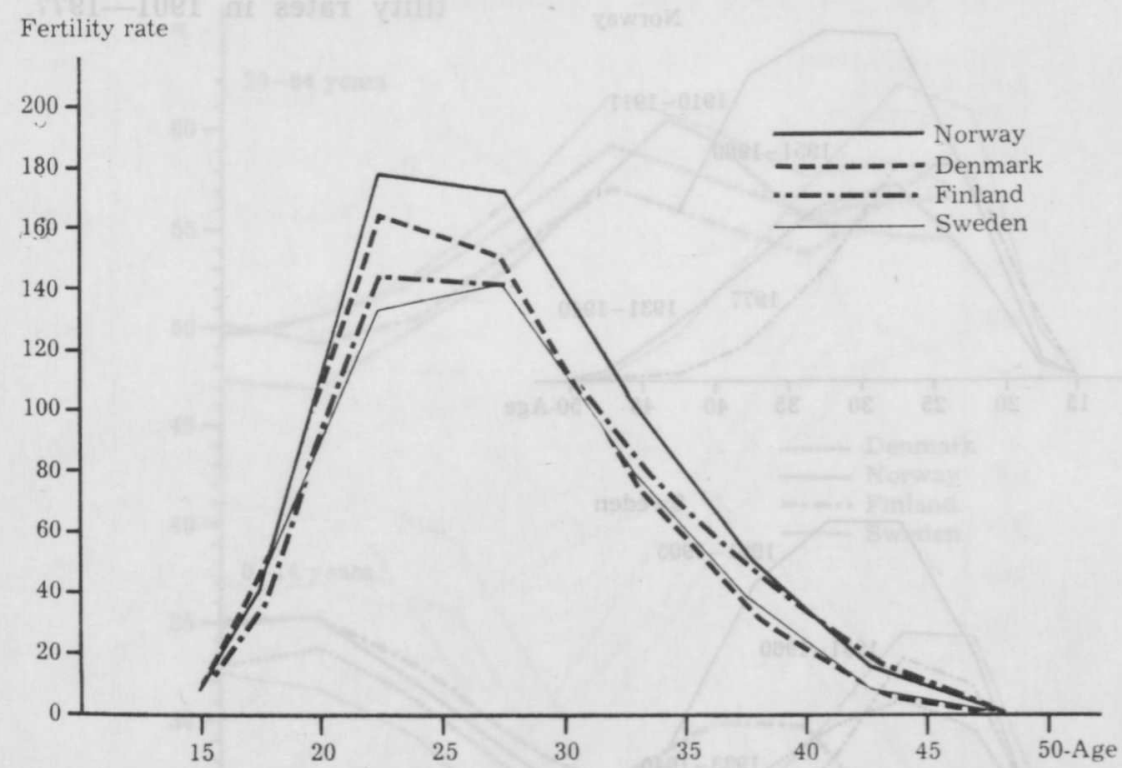

Sources: Yearbook of Nordic Statistics, 1978.

Levevilkår i Danmark, 1976.

Statistical Yearbook of Finland, 1977.

Historisk statistik för Sverige, 1721-1967: Del 1.

young people, adults of working age and old people in the four countries studied.

The most obvious change during the 20th century has been the decrease in the proportion of children (0-14 years). It declined rapidly from 1900 to 1940 , increased as a result of the postwar »baby boom» in the 1940 s (which in Norway and Finland continued in the 1950s), but turned definitely downwards after 1960. The proportion of children and youth has, for most of the period investigated, been highest in Finland. However, in 1975 the proportion of children was lower in Finland than in Norway and Denmark. The Swedish population has constantly included the fewest children proportionally.

In Norway neither the birth rate nor the percentage of children dropped after 1950 in the same way as in the other countries. This may be related to the low economic activity of Norwegian women.

The proportion of persons of working age (20-64 years) increased steadily from $47-50 \%$ in 1900 to $57-62 \%$ in 1940, as a result of the declining birth rate. After the Second World War a decreasing trend can be seen (with the exception of an increase in Finland after 1960). This is related to the decreasing death rate. Simultaneously, the proportion of elderly people has grown. The older age groups have expanded much more rapidly in Scandinavia than in Finland, where a real increase began in the 1960 s. In the middle of the 1970 s $11-15 \%$ of the population in the Nordic countries were at least 65 years old. 


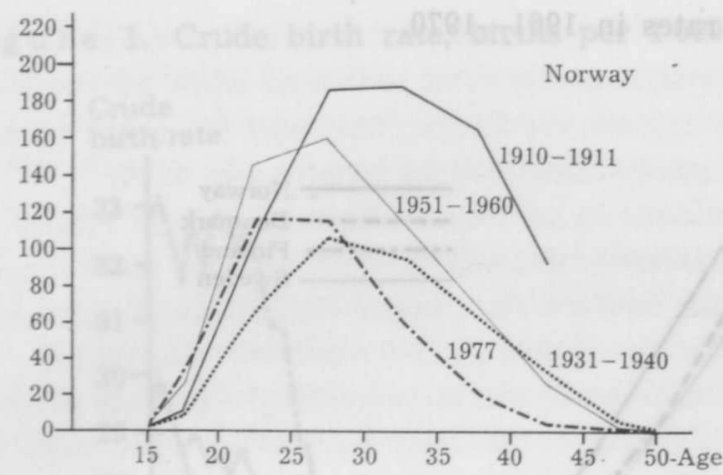

Figure 3. Age-specific fertility rates in 1901-1977.
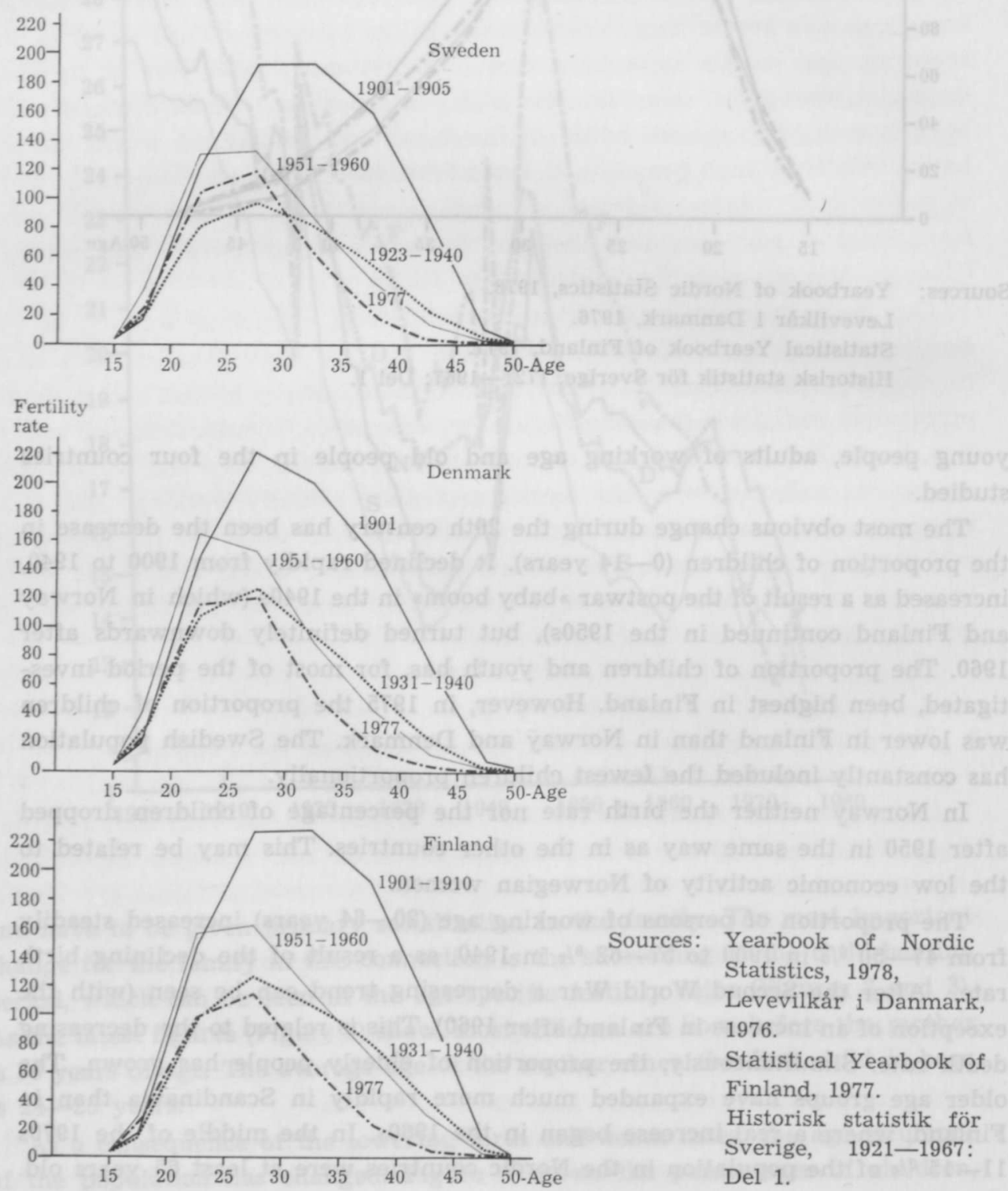
Figure 4. Population by age.

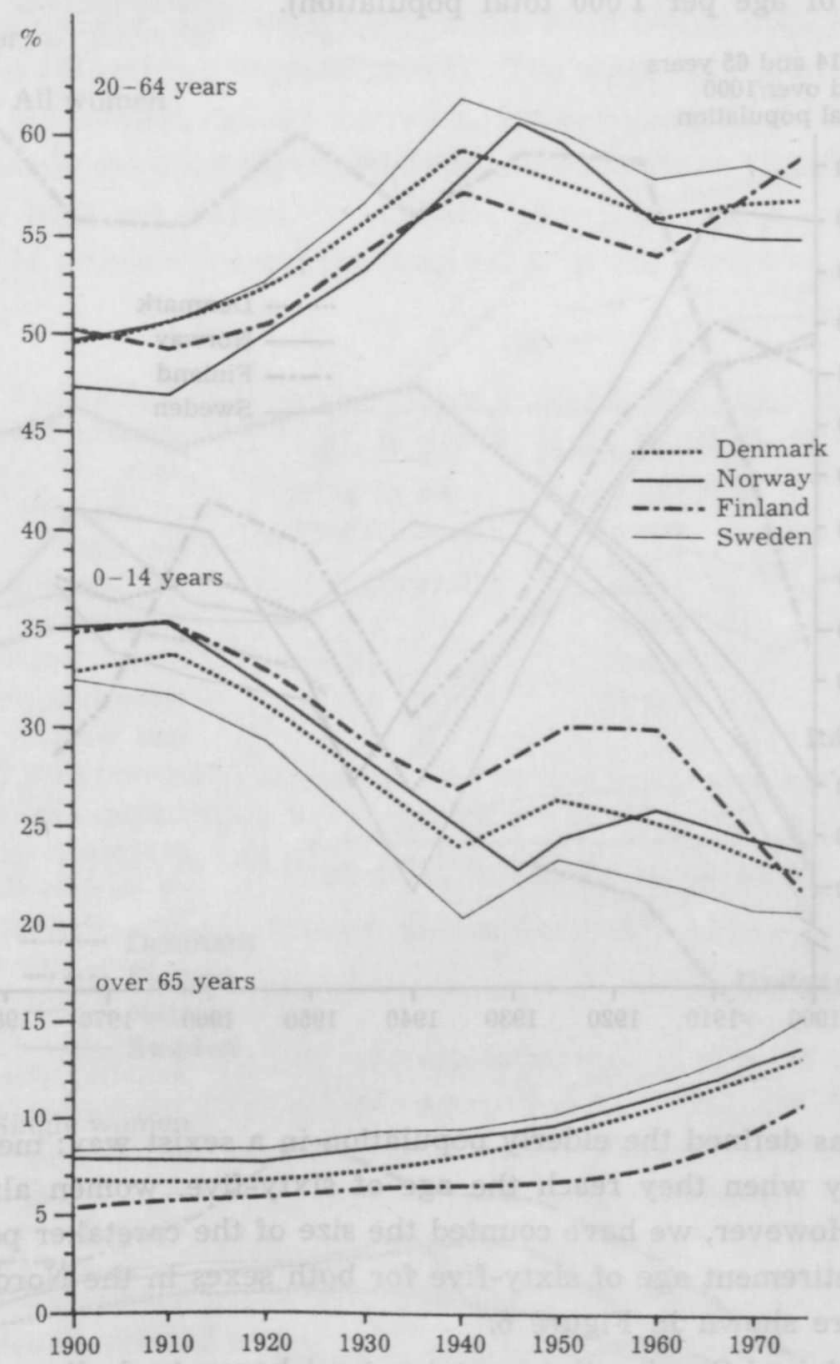

On the basis of data on the age structure of the four populations we have counted so-called dependency ratios, that is proportions of persons $0-14$ years and 65 years and over per 1000 population (Figure 5). They show a decline from $400-430$ in 1900 to about $300-330$ in 1940. After that, the proportion of dependants, children and old people, has again increased in comparison to people of working age. In 1975 the dependency ratio varied between 359 and 374 in Denmark, Norway and Sweden. In Finland it declined after 1960, and was only 326 in 1975 . The low birth rate has not yet been followed by as low a death rate as in the Scandinavian countries (see Valkonen and Notkola 1977).

We have also calculated the caring function of the family in the Nordic countries following the example of Robert M. Moroney (1976, 20-22). Unfor- 
$\mathrm{F}$ ig u re 5. Dependency ratio (ratio of the population $0-14$ and over 65 years of age per 1000 total population).

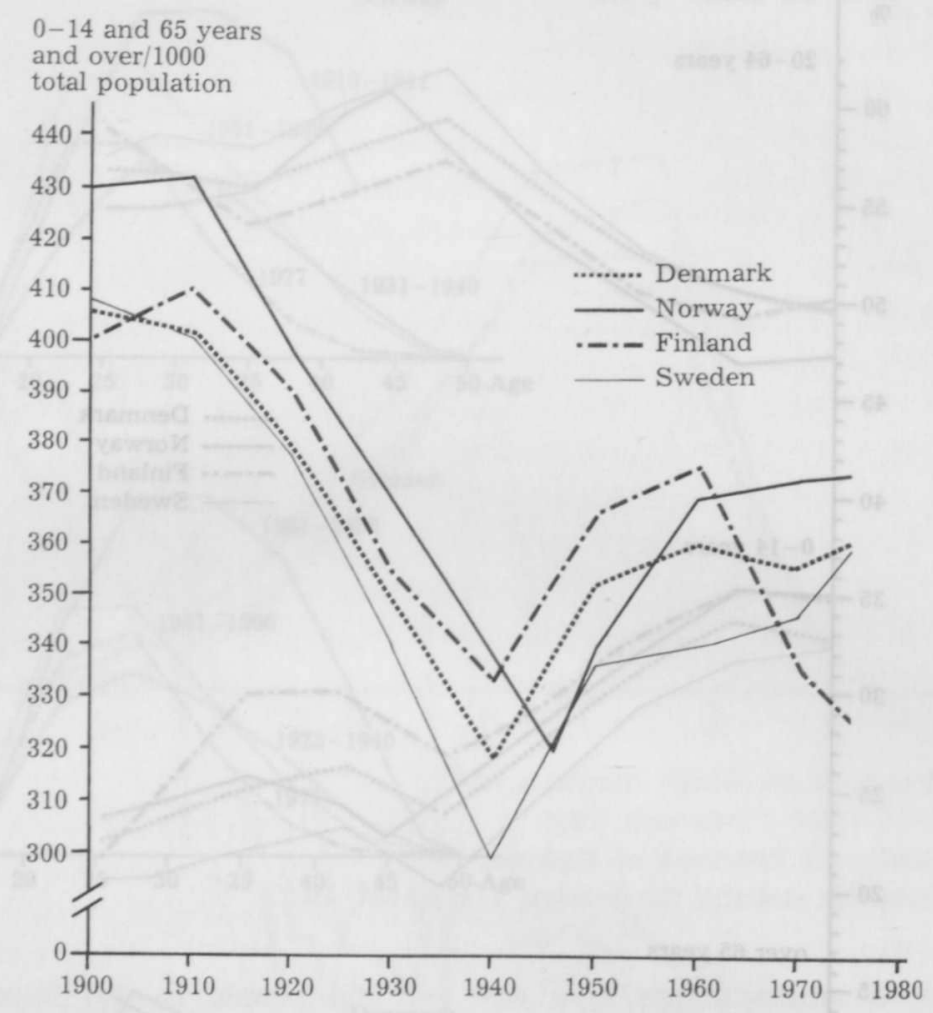

tunately he has defined the elderly population in a sexist way: men are classified as elderly when they reach the age of sixty-five, women already at the age of sixty. However, we have counted the size of the caretaker pool by using the general retirement age of sixty-five for both sexes in the Nordic countries. The results are shown in Figure 6.

In Denmark and Sweden the caretaker pool began to decline after 1940, in Norway after 1950, and in Finland only after 1960. However, the caretaker pool of single women started to diminish already after 1930 in Finland, and after 1946 in Norway, due to changes in marital status - see section 3 below. We can also compare the Nordic figures with those of the United Kingdom (Moroney 1976, 22) and Italy (Sgritta 1979, 50).

The sharp decline of the caretaker pool due to demographic changes is obvious in the Nordic countries as well as elsewhere in Europe. The employment of married women has also rapidly increased (Nordisk Ministerråds sekretariat 1979, 113). The percentages of married women in the labour force according to age group are shown in Figure 7. There are nowadays only few full-time housewives in the age group $45-60$, which according to Moroney has traditionally cared for the elderly. 
Figure 6. Women aged $45-59$ per 1000 elderly. ${ }^{a}$

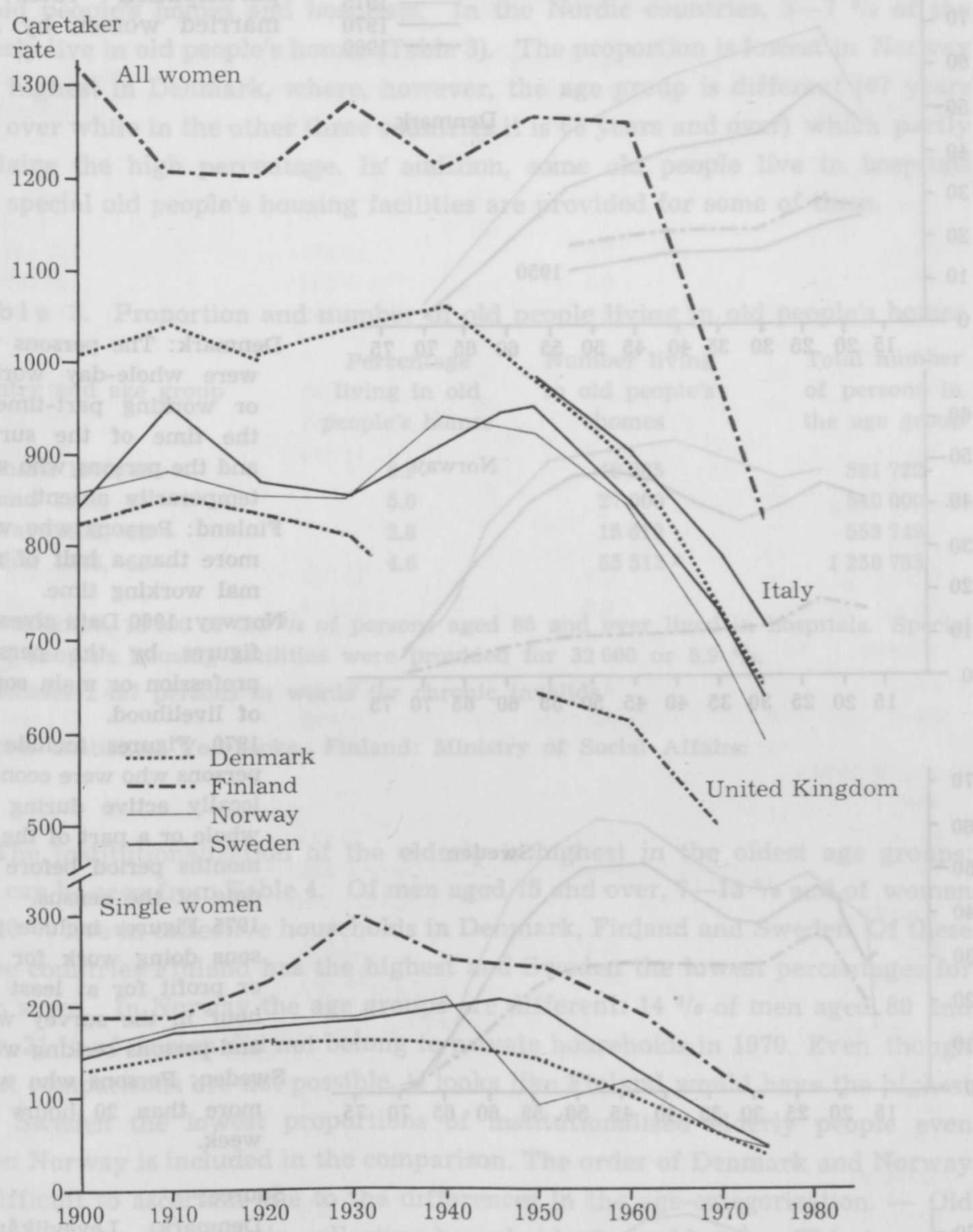

a In the Nordic countries persons aged 65 and over are defined as elderly. In Italy and the United Kingdom also women aged 60-64 years are included in the elderly population. Thus the rates are not quite comparable. Detailed comparisons are made in an earlier version of this article (Working paper 11, University of Helsinki, Department of Sociology, 1979). 
$\%$
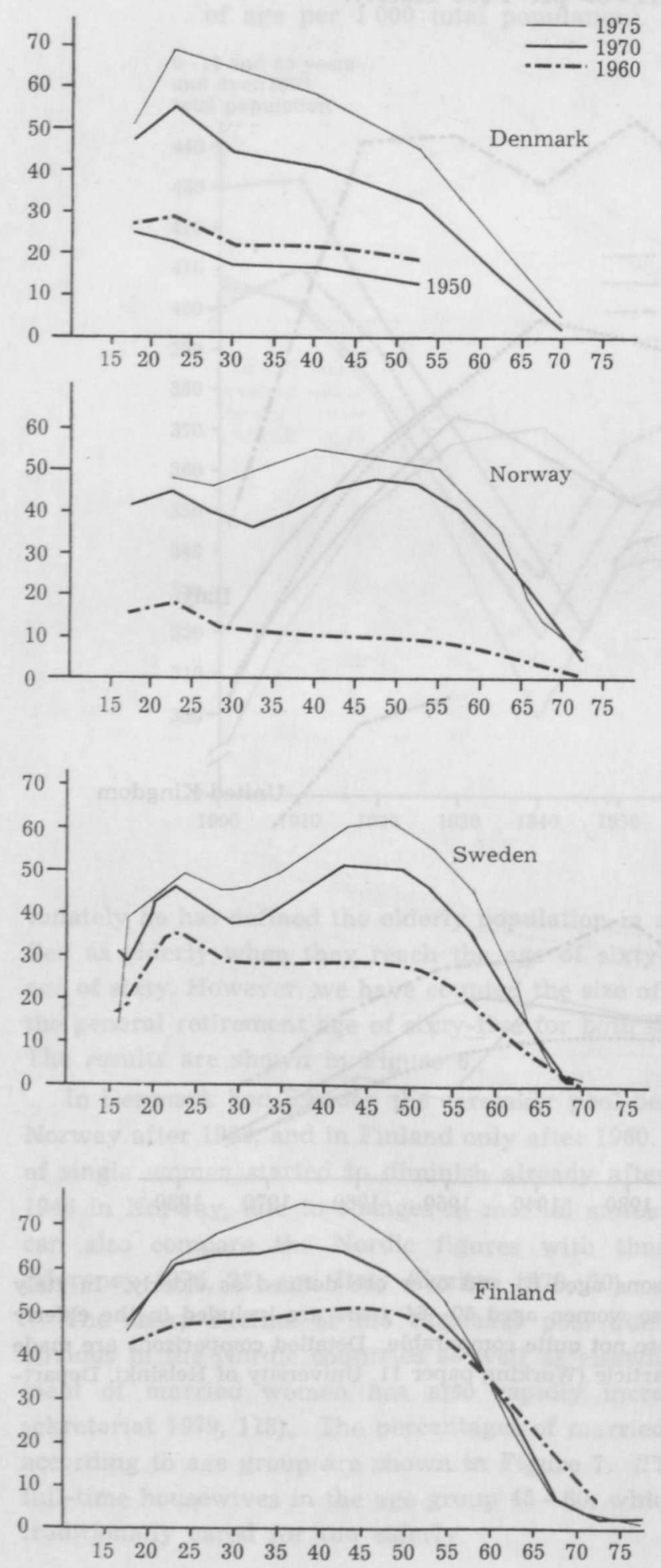

Figure 7. Labor force participation rates of married women by age.

Denmark: The persons who were whole-day workers or working part-time at the time of the survey, and the persons who were temporarily absent.

Finland: Persons who work more than a half of normal working time.

Norway: 1960 Data gives the figures by the person's profession or main source of livelihood.

1970 Figures include all persons who were economiccally active during the whole or a part of the 12months period before the date of the census.

1975 Figures include persons doing work for pay or profit for at least one hour in the survey week and persons seeking work.

Sweden: Persons who work more than 20 hours per week.

\section{Source:}

Denmark: Levevilkår i Danmark, 1976.

Finland: FOS VI C 104, 1970 II B; VI C 105 I A, 1975.

Norway: NOS XII 129, 1960 Hefte III. NOS A 693, 1970, Hefte II. NOS A 813, 1975.

Sweden: SOS, FoB 1975 Del 6:2; Folkräkningen, 1960 IX. 
As a result, more and more old people are living outside private households, in old people's homes and hospitals. In the Nordic countries, $3-7 \%$ of the elderly live in old people's homes (Table 3). The proportion is lowest in Norway and highest in Denmark, where, however, the age group is different (67 years and over while in the other three countries it is 65 years and over) which partly explains the high percentage. In addition, some old people live in hospitals and special old people's housing facilities are provided for some of them.

T a ble 3. Proportion and number of old people living in old people's homes.

\section{Country and age group}

Denmark 1976, 67-

Finland 1978, 65-1

Norway $1975,65-$

Sweden $1975,65-$

\section{Percentage}

living in old people's homes

\section{Number living \\ in old people's homes}

40065

27000

15619

555132
Total number of persons in the age group

581722

540000

553749

1250785

1 In addition, 18000 or $3.3 \%$ of persons aged 65 and over lived in hospitals. Special old people's housing facilities were provided for 32000 or $5.9 \%$.

2 Includes 2497 persons in wards for chronic invalids.

Source: Statistical Yearbooks. Finland: Ministry of Social Affairs.

The institutionalization of the elderly is highest in the oldest age groups; this can be seen from Table 4. Of men aged 75 and over, $7-13 \%$ and of women $9-20 \%$ live in collective households in Denmark, Finland and Sweden. Of these three countries Finland has the highest and Sweden the lowest percentages for both sexes. In Norway the age groups are different: $14 \%$ of men aged 80 and over, $21 \%$ of women did not belong to private households in 1970 . Even though exact comparisons are not possible, it looks like Finland would have the highest and Sweden the lowest proportions of institutionalized elderly people even when Norway is included in the comparison. The order of Denmark and Norway is difficult to ascertain due to the differences in the age-categorization. - Old women more often live in collective households than old men. This is partly related to their higher average age.

Even though the number of children has considerably diminished, the family nowadays has more problems than earlier in taking care of them. The employment rates of mothers of small children are high (Table 5). Children's day care is not yet adequately provided even in Sweden, which has made the most efforts to supply it (Kamerman 1978, 32-33). The development of public day care has been slow, but there is no longer suspicion or fear towards it, as there used to be in some cases. 
Table 4. Proportion of elderly persons living in collective households according to age and sex, per cent.

$\begin{array}{lcc}\text { Country, sex } & \begin{array}{c}\text { Percentage living } \\ \text { in collective }\end{array} & \begin{array}{c}\text { Number living } \\ \text { in collective }\end{array} \\ \text { households } & \text { households }\end{array}$
Total number of persons

Norway 1970

Men

$\begin{array}{lrrr}60- & 3.5 & 10957 & 317123 \\ 70- & 6.4 & 8822 & 137957 \\ 80- & 14.2 & 4862 & 34120 \\ \text { Women } & & & \\ 60- & 5.0 & 19798 & 392292 \\ 70- & 9.3 & 17588 & 188753 \\ 80- & 21.2 & 11148 & 52603\end{array}$

Sweden 1975

Men

$67-$

$75-$

Women

67-

\section{Denmark 19701}

Men

65-

5.2

13919

267784

$75-$

\section{Women}

$65-$

6.9

23551

342457

$75-$

Finland 1975

Men

65-

7.3

13719

187363

75-

12.9

6385

49386

\section{Women}

65-

10.0

32229

320708

$75-$

19.7

20831

105885

1 Includes also those living in hotels or staying temporarily in hospitals.

Source: Norway, NOS A 448, Table 1, pp. 24-25, NOS 653, Table 2, pp. 20-21 and unpublished data, taken from Olof Tvede, Eldre i levekårsundersökelsens intervju analyse av representativite og frafall. Arbeidsnotat fra Levekårsundersökelsen nr. 69. 1975.

Sweden, SOS FoB 1975, Del 5: 2.

Denmark, DOS, Folke- og boligtellingen 1970, C2.

Finland, FOS VIC: 105, part 3, 1975. 
$\mathrm{Table} 5$. Labour force participation rates of mothers according to age of youngest child.

1960

1970

1975

Denmark 1

$$
\begin{aligned}
& 0-2 \\
& 3-6 \\
& 7-17 \\
& 0-17
\end{aligned}
$$

43
49
54
50

Finland 2

0 - 6

$7-15$

$16-17$

$0-17$

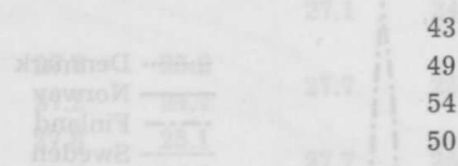

Norway 3

$$
\begin{aligned}
& 0-6 \\
& 7-14 \\
& 0-14
\end{aligned}
$$

\section{Sweden 2}

$$
1960^{4}
$$

$0-6$

$7-15$

$0-17$

$$
\begin{array}{lll}
15 & \text { (age } & 0-5 \text { ) } \\
26 & \text { \$ } & 6-15 \\
21 & \text { » } & 0-15
\end{array}
$$
32
49 (age $7-17$ )

(age $7-15$ )

(age $0-15$ )

5 (age $0-2$ )

46 " $3-6$

58 » $7-10$

61 » $11-15$

48 » $0-15$

1 Including part-time workers.

2 Excluding part-time workers.

3 Participation rates of married women, including part-time workers.

4 Participation rates of married women.

Source: Levevilkår i Danmark 1976.

FOS VI C 104: VIII, FOS VI C 105: III.

NOS Folketelling 1960 VII, NOS A 693, NOS A 813.

SOS Folkräkningen 1960 IX, FoB 1970 Del 10, FoB 1975 Del 6: 2.

\section{Marriage}

With the exception of Sweden, the proportion of persons getting married during a year per mean population is at present about the same as at the beginning of the century (Figure 8). In Sweden, however, it is considerably lower, due to the popularity of cohabitation without marriage (Lewin 1979, Trost 1980).

But there have also been periods when the marriage rate has been higher than it is nowadays in the 1970 s and higher than it was in 1900-1935. In about $1935-1955$ and again in $1965-70$ very many people got married. The first boom may be related to a recovery from the low marrying years during the Depression, but also to changes in marriage age (Table 6). The second marriage boom 
Figure 8. At each year married persons per 1000 total population.

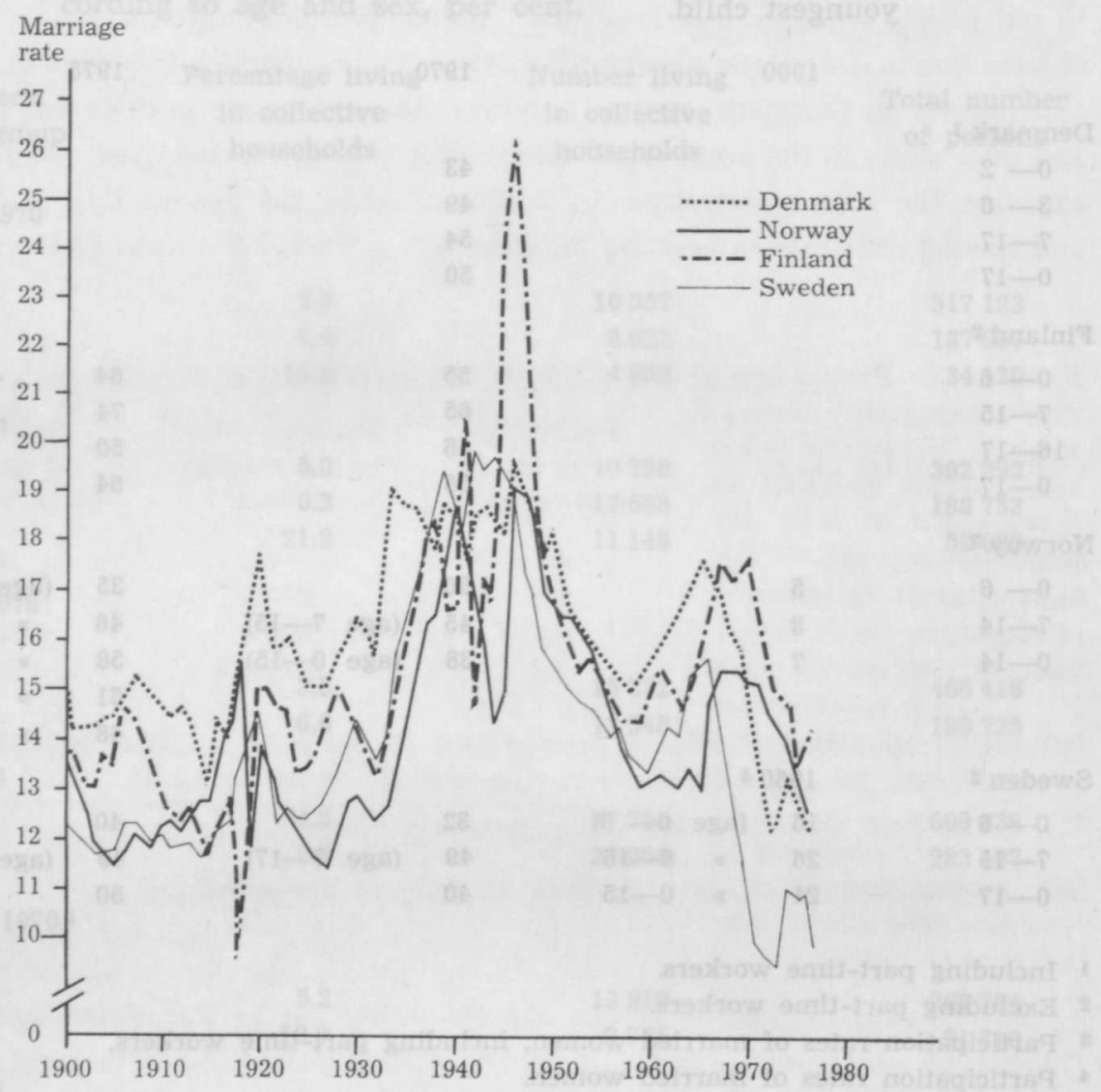

can be explained by the post-war baby boom, whose products reached their marriage age at the end of the 1960s.

Inter-country differences in marriage rates are relatively small. In addition to the Swedish departure from the general pattern in the 1970 s, one can notice that in Denmark more marriages have taken place than elsewhere in the Nordic countries, at least in 1900-1937 and 1949-1965.

In the Nordic countries, age at marriage kept rising until the Second World War, as Table 6 shows. A new increase is taking place in the 1970 s. It is probably related to unmarried cohabitation, which has become relatively customary as the first stage of marriage (e.g. Aromaa, Cantell \& Jaakkola 1979, Koch-Nielsen 1978, Lewin 1979, Trost 1980).

Postponement of marriage until the middle or late twenties, which happened at the beginning of the century, stopped around 1940. As a consequence, marriage rates increased as was pointed out above. 
T a ble 6. Average age at first marriage.

\begin{tabular}{|c|c|c|c|c|c|c|c|c|}
\hline & Der & mark & & land & & rway & & reden \\
\hline & Males & Females & Males & Females & Males & Females & Males & Females \\
\hline $1901-1905$ & & & & & 27.7 & 25.7 & & \\
\hline $1906-1910$ & & & 27.1 & 24.9 & 27.9 & 25.7 & 28.7 & 26.4 \\
\hline $1911-1915$ & 27.7 & 25.2 & & & 27.8 & 25.6 & & \\
\hline $1916-1920$ & 27.2 & 24.7 & 27.7 & 25.2 & 27.6 & 25.4 & 29.1 & 26.5 \\
\hline $1921-1925$ & 27.8 & 25.1 & & & 28.1 & 25.6 & & 265 \\
\hline $1926-1930$ & 27.7 & 24.9 & 27.7 & 25.3 & 28.7 & 26.0 & 29.4 & 26.5 \\
\hline $1931-1935$ & 27.6 & 24.9 & & & 29.1 & 26.3 & 29.4 & 26.5 \\
\hline $1936-1940$ & 27.5 & 24.5 & 28.3 & 25.9 & 29.3 & 26.4 & 29.4 & 26.5 \\
\hline $1941-1945$ & matal- & & & & 29.2 & 26.4 & 28.7 & 26.1 \\
\hline $1946-1950$ & 27.21 & 24.11 & 28.2 & 25.7 & 29.3 & 26.4 & 28.5 & 25.8 \\
\hline $1951-1955$ & $26.3^{2}$ & $23.2^{2}$ & & & 28.5 & 25.5 & 28.0 & 25.3 \\
\hline $1956-1960$ & $26.0^{3}$ & $22.9^{3}$ & 26.3 & 24.4 & 27.7 & 24.5 & 27.6 & 24.6 \\
\hline $1961-1965$ & & & & & 26.4 & 23.4 & 26.6 & 23.7 \\
\hline $1966-1970$ & $24.9^{4}$ & 22.74 & 25.3 & 23.0 & 25.3 & 22.8 & 26.0 & 23.6 \\
\hline $1971-1975$ & & & & & 25.2 & 22.7 & & \\
\hline 1976 & & & 25.5 & 23.7 & & & 27.8 & 25.3 \\
\hline 1977 & & & & & & & 28.1 & 25.5 \\
\hline 11950 & & & & & & & & \\
\hline $\begin{array}{ll}2 & 1957\end{array}$ & & & & & & & & \\
\hline $\begin{array}{ll}3 & 1960\end{array}$ & & & & & & & & \\
\hline $\begin{array}{ll}4 \quad 1969\end{array}$ & & & & & & & & \\
\hline
\end{tabular}

Source: Historical Statistics of Norway and Sweden, Statistical Yearbooks.

The experience of marriage has been more common since 1940 than before that. Figure 9 shows how the proportion of ever married (presently married, divorced and widowed) has developed during this century in the age group 3539 , in which most people have already become married. In 1910-1930 fewer than three quarters of women ever got married in Finland, Norway and Sweden. Only in Denmark did the marriedness of women exceed $80 \%$. The very high probability of women getting married in Denmark has continued up to this decade: $94 \%$ of Danish women have, by the age of $35-39$, lived at least for a while in one or more marital union. The present day Norwegian women are also very often married or at least have been so. Spinsters are rare in these two countries. In Finland and Sweden about a tenth of women in their late thirties are still spinsters. Among men, experiences of married life follow the same time trends as among women. It is somewhat surprising to notice that there are relatively more bachelors than spinsters nowadays in the Nordic countries. Earlier the situation was the opposite: a higher percentage of males than of females had been married by the time they were approaching the age of forty. 
Figure 9. Percentages of ever married in the age group $35-39$, whole country.
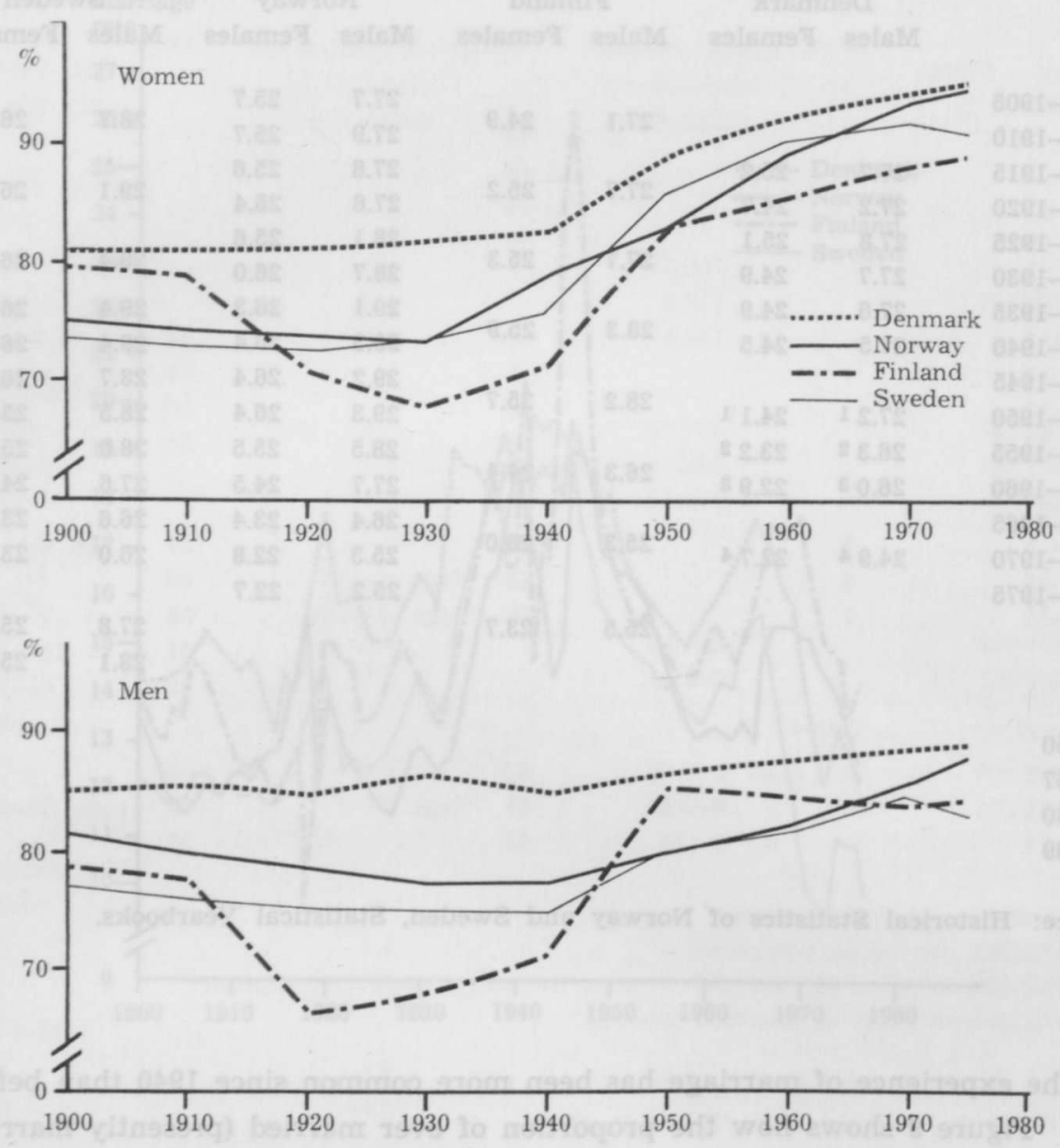

Proportions of ever married men and women in the age group 35-39 years are presented separately for urban and rural areas in Figure 10. The figure reveals that the high marriedness of the Danes does not disappear when the type of community is controlled. The low proportion of Finns getting married in 1920 - 1940 was particularly obvious in urban districts, but the same phenomenon could be seen in rural areas, too.

At the beginning of the 20th century, there was a wide gap between urban and rural areas in the percentages of ever married women. Industrialization and urbanization gave rise to a surplus of women in towns and cities. As a consequence, in urban areas many women remained single. The rural-urban difference in the percentage of ever married women aged 35-39 was in Finland $17-18$ in $1900-1920$ and in Sweden $12-14$ in $1900-1910$. In Denmark and Norway it never exceeded ten percentage points. This rural-urban difference 
Fig ure 10. Percentages of ever married in the age group $35-39$.
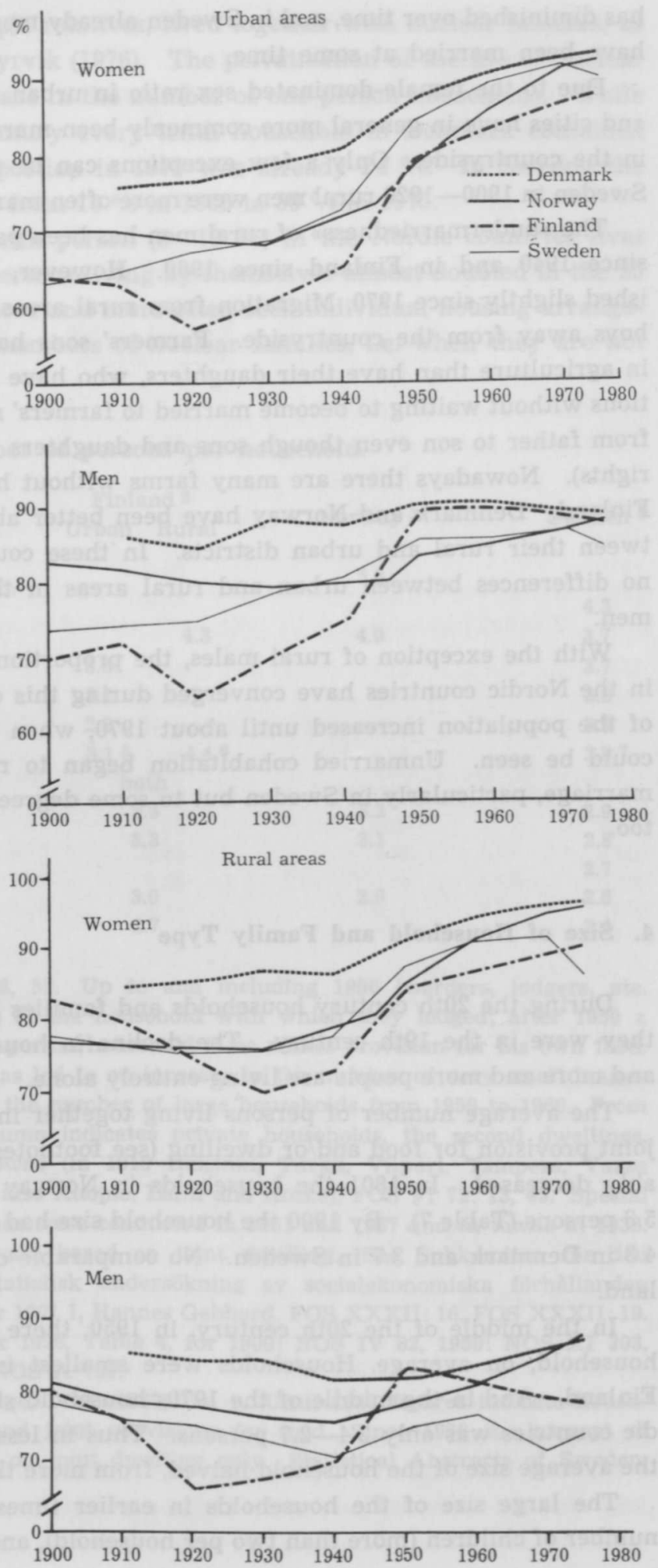
has diminished over time, and in Sweden already more urban than rural women have been married at some time.

Due to the female-dominated sex ratio in urban areas, men living in towns and cities have in general more commonly been married than have those living in the countryside. Only a few exceptions can be mentioned: in Finland and Sweden in 1900 - 1920 rural men were more often married than were urban men.

The »undermarriedness» of rural men has been particularly large in Sweden since 1940 and in Finland since 1960. However, in Sweden it has diminished slightly since 1970. Migration from rural areas has taken more girls than boys away from the countryside. Farmers' sons have remained more loyally in agriculture than have their daughters, who have moved into urban occupations without waiting to become married to farmers' sons (the farm usually goes from father to son even though sons and daughters have the same inheritance rights). Nowadays there are many farms without housewives in Sweden and Finland. Denmark and Norway have been better able to retain a balance between their rural and urban districts. In these countries there is practically no differences between urban and rural areas in the proportions of married men.

With the exception of rural males, the proportions of ever married persons in the Nordic countries have converged during this century. The marriedness of the population increased until about 1970, when again a new development could be seen. Unmarried cohabitation began to replace the early years of marriage, particularly in Sweden but to some degree in Denmark and Finland, too.

\section{Size of Household and Family Type}

During the 20th century households and families have become smaller than they were in the 19th century. The decline in household size still continues, and more and more people are living entirely alone.

The average number of persons living together in the same household with joint provision for food and/or dwelling (see footnotes to Table 7) has considerably decreased. In 1801 the households in Norway consisted, on average, of 5.3 persons (Table 7). By 1900 the household size had declined to 4.9 in Norway, 4.3 in Denmark and 3.7 in Sweden. No comparable data are available for Finland.

In the middle of the 20th century, in 1950, there were 2.9-3.6 persons per household, on average. Households were smallest in Sweden, and largest in Finland. And in the middle of the 1970 s household size on average in the Nordic countries was only $2.4-2.7$ persons. Thus in less than two hundred years, the average size of the household halved, from more than five to two and a half.

The large size of the households in earlier times was related to the high number of children (more than two per household), and to the fact that servants 
and other people, for example relatives, lived together with nuclear families, as has been shown by Ståle Dyrvik (1976). The privatization of the life of nuclear families has led to an increase in the number of one-person households. While at the beginning of the century every tenth household in Denmark contained only one member, the proportion in 1975 was already $24 \%$. In Sweden the corresponding increase was from $16 \%$ in 1860 to $30 \%$ in 1975.

However, only every tenth person $(8-12 \%)$ in the Nordic countries lives alone. The proportion of persons living by themselves almost doubled in the 25 years after 1950. People more and more often seek individual housing arrangements when they are not members of nuclear families, i.e. when they are not

Table 7. Average number of persons per household.

\begin{tabular}{|c|c|c|c|c|c|c|}
\hline Year & \multicolumn{2}{|c|}{ Denmark 1} & $\begin{array}{l}\text { Finla } \\
\text { Urban }\end{array}$ & $\begin{array}{l}\text { and }{ }^{2} \\
\text { Rural }\end{array}$ & Norway ${ }^{3}$ & Sweden \\
\hline 1801 & & & & & 5.3 & \\
\hline 1860 & & & & & & 4.3 \\
\hline $1900 / 01$ & & & & 4.3 & 4.9 & 3.7 \\
\hline 1910 & & & 3.6 & 1285 & 7.18 & 3.7 \\
\hline 1920 & & & 3.1 & a.tab & $a_{20}$ & 3.6 \\
\hline 1930 & & & 2.8 & 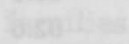 & 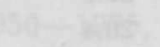 & 3.5 \\
\hline 1940 & & & $3.1^{5}$ & 4.46 & 8.89 & $2.8^{7}$ \\
\hline \multicolumn{7}{|c|}{ both } \\
\hline 1950 & & & & 3.6 & 3.3 & 2.9 \\
\hline 1960 & 2.9 & 3.0 & & 3.3 & 3.1 & 2.8 \\
\hline 1965 & 2.8 & 2.9 & & & & 2.7 \\
\hline 1970 & 2.6 & 2.7 & & 3.0 & 2.9 & 2.6 \\
\hline 1975 & & 2.7 & & 2.7 & & 2.4 \\
\hline
\end{tabular}

1 Levevilkår i Danmark 1976, 52. Up to and including 1950 boarders, lodgers, etc. were regarded as members of the household with which they lodged; after 1950 a lodger is regarded as a one-person household if he makes provision for his own food. This change in definition has led to an increase in the number of very small households, and to a decrease in the number of large households from 1950 to 1960 . From 1960 onwards the first column indicates private households, the second dwellings.

2 Census data from large towns (in 1910 Helsinki, Turku, Viipuri, Tampere, Vaasa and Oulu, in 1920 and 1930 also Kuopio, Lahti and Kotka), FOS VI 72: 13, 43. Special housing studies in rural areas were conducted in 1901 and 1937 and in towns in 1938. Figures in 1937 and 1938 are based on joint dwelling. See Subkomiten för den obesuttna befolkningen, Statistisk undersökning av socialekonomiska förhållanden Finlands landskommuner år $1901 \mathrm{I}$, Hannes Gebhard. FOS XXXII: 16. FOS XXXII: 19.

3 Data for 1801: Ståle Dyrvik 1976, Table 4, for 1900: NOS IV 82, 1950: NOS XI 303, 1960: NOS XII 151, 1970: NOS A 739.

4 Historisk statistik för Sverige, 1720-1967, Del 1. Until 1945 figures indicate household with joint dwelling and joint provisions for food. Since 1950 the concept of private household is based on joint dwelling only. Statistical Abstracts of Sweden.

51938.

61937.

71945. 
married, or do not have children under the age of majority, or are not themselves under the age of majority.

In the statistics "families» include persons related to each other by either marital or parental ties. The proportion of families which comprise married couples without children has grown in Finland and Norway since 1950 (Table 8).

T a b le 8. Family type in $1950-1975$, per cent.

\begin{tabular}{|c|c|c|c|c|}
\hline \multirow[t]{2}{*}{ Year } & $\begin{array}{l}\text { Married couple } \\
\text { without children }\end{array}$ & $\begin{array}{l}\text { Married couple } \\
\text { with children }\end{array}$ & $\begin{array}{l}\text { Woman with } \\
\text { children }\end{array}$ & $\begin{array}{l}\text { Man with } \\
\text { children }\end{array}$ \\
\hline & Denmark 1 & 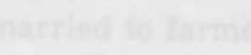 & 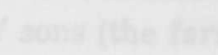 & \\
\hline \multirow[t]{2}{*}{1970} & 34.0 & $56.7+96$ & 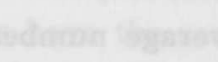 & 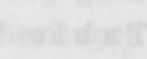 \\
\hline & Finland 1 & & 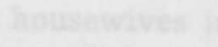 & \\
\hline 1950 & 19.0 & 63.8 & 14.8 & 2.4 \\
\hline 1960 & 20.1 & 65.5 & 12.5 & 1.9 \\
\hline 1970 & 23.0 & 63.6 & 11.7 & 1.7 \\
\hline \multirow{2}{*}{1975} & 24.4 & 61.9 & 11.8 & 1.9 \\
\hline & Norway 1 & 64 & 2.8 & 10100 \\
\hline 1950 & 21.7 & 68.1 & 7.0 & 3.1 \\
\hline 1960 & 25.2 & 65.5 & 6.4 & 2.9 \\
\hline 1970 & 28.4 & 62.6 & 7.5 & 1.4 \\
\hline \multirow[t]{2}{*}{1977} & 28.9 & 60.1 & 9.2 & 1.8 \\
\hline & Sweden 2 & 45 & 15 & \\
\hline 1950 & 42.3 & 52.4 & 4.7 & 0.6 \\
\hline 1960 & 44.5 & 49.9 & 5.0 & 0.6 \\
\hline 1970 & 45.2 & 46.7 & 7.5 & 0.7 \\
\hline 1975 & 44.9 & 42.6 & 11.3 & 1.1 \\
\hline
\end{tabular}

1 All unmarried children are included.

2 In 1950 and 1960 only children aged $0-16$ years and in 1970 and 1975 children aged $0-17$ years are included.

\section{Source:}

Denmark: Levevilkår i Danmark, 1976

Finland: FOS VI C: 105 III

Norway: NOS XI 303, XII 151, NOS A 739, A 951

Sweden: SOS Folkräkningen 1950 II

Statistiska Meddelanden B 1964: 3

SOS FoB 1970 Del 9

SOS FoB 1975 Del 5:2

In Sweden a similar increase stopped in 1970. As the proportion of married couples without children has increased, that of families with children has decreased. The proportion of families with children is larger in Finland and Norway than in Sweden, partly for technical reasons: in Finland and Norway all unmarried children, regardless of age, are included in the statistics. In Sweden 
only children under 17 (in 1950 and 1960) or 18 (in 1970 and 1975) are counted as family members.

In all three countries there are considerably more »woman with children» than "man with children" families. It has been customary after divorce for children to stay with their mother, not with their father. In addition, the life expectancy of men is lower than that of women. Thus there are more widows than widowers with children. However, the proportion of families consisting of a man with children is slightly increasing, perhaps because of a change in attitudes towards parental roles after divorce.

The proportion of one-parent families declined in Finland and Norway between 1950 and 1970, perhaps because of an increase in life expectancy. From 1970 onwards a small increase can be seen. It is probably connected with the growing divorce rate, as well as with cohabitation without marriage, which has spread to some extent also to Finland and Norway, as well as occurring in Sweden and Denmark. In Sweden one-parent families have steadily increased since 1950. For Denmark we have not yet found the data.

People living alone are not included in the statistical concept of family. Thus the average size of families is higher than that of households (Table 9). But

T a b le 9. Persons and children in families in 1950-1975, per cent.

\begin{tabular}{|c|c|c|c|c|c|c|}
\hline \multirow{2}{*}{ Year } & \multicolumn{3}{|c|}{ Persons per family } & \multicolumn{3}{|c|}{ Children per child-family } \\
\hline & F & $\mathrm{N}$ & S 1 & $\mathrm{~F}^{2}$ & $\mathrm{~N}^{3}$ & S 4 \\
\hline 1950 & 3.72 & 3.70 & 2.97 & 2.24 & 1.97 & 1.77 \\
\hline 1960 & 3.72 & 3.40 & 2.90 & 2.27 & 1.88 & 1.72 \\
\hline 1970 & 3.47 & 3.35 & 2.89 & 1.99 & 1.94 & 1.76 \\
\hline 1975 & 3.29 & & 2.84 & 1.78 & 1.89 & 1.74 \\
\hline
\end{tabular}

1 Excluding children aged 17 and over (1950 and 1960) or 18 and over (1970 and 1975) years.

2 Children aged $0-18$ years.

3 In 1950 and 1970 children aged $0-15$ years, in 1960 0-14 years, in $19770-16$ years.

4 In 1950 and 1960 children aged $0-16$, in 1970 and $19750-17$ years.

$\begin{array}{ll}5 & 1977 .\end{array}$

Source: See Table 8.

families have also become smaller than they used to be, partly because there are more childless and one-parent families, partly because the number of children per family with children has decreased. In Finland the decline in the number of children per family with children has been more marked than in Norway and Sweden. In the middle of the 1970 s there were on average $1.7-1.9$ children in families with children. Unfortunately these figures are not quite comparable because of the exclusion of grown-up children from the Swedish statistics. 


\section{Conclusion}

In the four Nordic countries, Denmark, Finland, Norway and Sweden, the demographic trends influencing life patterns of families are relatively similar. During the 20th century the type of economic activity of the population has dramatically changed. The Nordic countries have industrialized, and they are already at the post-industrial stage of development. In Scandinavia, about $45 \%$ of economically active men and $75 \%$ of women work in the service sector of the economy; in Finland $35 \%$ of active men and $61 \%$ of women do so (in 1975).

The increase in non-agricultural economic activity among men has perhaps reached its peak. Adult men can nowadays afford to study and to live in retirement to a greater extent than before. Among women, however, an opposite trend can be seen: the economic activity of women continues to increase. More than every second adult woman is economically active in three of the four countries studied. Norway still has more full-time housewives than the other three countries, but it no longer deviates from the others as much as it did in the middle of the 20th century. The high proportion of women in the economically active population in Finland is not a consequence of an especially high activity rate of women. It is mostly explained by the low activity of men, who have only slowly moved from agriculture to industry and service occupations. Finnish women have been quicker than Finnish men to change into modern occupations.

The increasing economic activity of women outside the home has changed the situation in the family. There are now very few unpaid caretakers of children and old people available in private homes throughout the day. Even mothers of small children work to a great extent outside the home. In Scandinavia women often, indeed in almost half the cases, work only part-time. In Finland most women work full-time, carrying the double burden of paid work outside and unpaid work inside the home.

In the Nordic countries, as in all developed countries, birth and death rates have considerably declined during this century. Instead of a large number of children, we nowadays have more and more elderly, who need care. And there are no caretaker pools of non-employed middle-aged women in the homes - if there ever were such in the Nordic countries, as there were in England according to Robert Moroney.

The proportion of the population which is married has until recently increased. Spinsters and bachelors have become rare; those young people who cohabitate without being married cannot be considered unmarried in the traditional meaning of the term. Thus more and more people can at least for a while during their life-time live in a marital union. Few people are nowadays excluded from human community and sexual life because they have not found a marital partner. However, an increasing number also go through a separation 
or divorce process, the consequence of which will be studied by the other team working in the European family project connected with the Vienna Center.

Household size has diminished. The proportion of people living alone has grown. The trend towards one-person households is connected with a rising standard of living and a desire for privacy. But it may also create problems of isolation, lack of human contact and lack of help, when needed. The family is not around when a person living alone falls ill or gets old. The society has to organize services for people living by themselves, in order to compensate for the unpaid services usually provided by household members.

The service sector of the economy has grown and will continue to grow in the future. This is partly related to changes in the life patterns of the families. But we do not yet know how well the functions earlier fulfilled by the family can be taken over by society. In our comparative family study we shall investigate problems which follow changes in the structure and life patterns of families. We shall also explore those coping mechanisms which are emerging in order to solve problems created by family changes in European societies.

\section{References}

Albrektsen, Beatrice Halsaa, Kvinner og politisk deltakelse, Oslo: Pax Forlag A/S 1977. Aromaa, Kauko, Ilkka Cantell \& Risto Jaakkola, Pariside yhä useammin virallisesti vahvistamaton, Sosiaalinen Aikakauskirja 1, 1979, pp. 46-50.

Dyrvik, Ståle, Barnet i familien og slektskrinsen, stencil 1978.

Eduards, Maud, Kvinnor och politik, Stockholm: Liber Förlag 1977.

Eichler, Margit, The Industrialization of Housework, Ontario Institute for Studies in Education, Toronto, paper presented at the NCFR meetings, October 1976, New York.

Finlands Officiella Statistik XXXII: 25, Åldringarnas bostadsförhållanden i städer och köpingar 1962.

Haavio-Mannila, Elina, Kotitöiden jako suomalaisissa perheissä, käsikirjoitus 1979.

Haavio-Mannila, Elina, Suomalainen nainen ja mies, Porvoo: WSOY 1968.

Haavio-Mannila, Elina \& Matti Kortteinen, Demographic, Economic and Cultural Determinants of Women's Work and Education, paper presented at the 9th World Congress of Sociology, Uppsala, August 1978.

International Labour Office, Year Books of Labour Statistics, Geneve, different years. Kamerman, Sheila, »Work and Family in Industrialized Societies», SIGNS: Journal of Women in Culture and Society, Summer 1979.

Koch-Nielsen, Inger, Forældremyndighed og samkvemsret i papirløse parforhold. Socialforskningsinstitutets meddelelse 24, København 1978.

Kolberg, Jon Eivind, Utstøting og profesjonsdannelse — to sider av samme sak? Sosiologi i dag Vol. 8, No. 4, 1978.

Levnadsförhållanden, Rapport nr 2. Statistiska centralbyrån, Stockholm 1976.

Lewin, Bo, Om ogift samboende i Sverige, Uppsala: Acta Universitatis Upsaliensis, Studia Sociologica Upsaliensia 15, 1979.

Liljeström, Rita \& Edmund Dahlström, Förändringar i livsmönster; i hem-, arbets- och samhällsliv, Göteborgs universitet, Sociologiska institutionen, Mars 1979.

Martinsen, Kari og Kari Waerness, Plei uten omsorg? Norsk sykepleie mellan pasient og profesjon, Oslo: Pax Forlag A/S, 1979. 
Mitchell, B. R., European Historical Statistics 1750-1970, London: Macmillan 1975.

Moroney, Robert M., The Family and the State - Considerations for Social Policy, London: Longman 1976.

Nordisk Ministerråds sekretariat i Oslo, Tiltak for likestilling mellan kvinner og menn på arbeidsmarkedet i Norden, Nordiska utredningar (NU) A 1979:2, Stockholm 1979.

Sgritta, G. B., Famiglia e instistuzionidi pubblico servizio in contesto urbano (Family and public service institutions in an urban context), in Familia e instituti di ricovero: Pubblico e privato nella riforma dell'assistenza, Rivista Italiana di dritto sociale, Rom 1979.

Trost, Jan, Unmarried Cohabitation, Stockholm: International Library 1980.

United Nations, Demographic Yearbooks, New York, different years.

Valkonen, T. and Notkola, V., Influence of socioeconomic and other factors on the geographic variation of mortality in Finland, Sweden and Norway. Yearbook of Population Research in Finland XV: 9-30, 1977.

Wadel, Cato, „Hva er arbeid? Noen refleksjoner om arbeid som aktiviteet og begrep», Tidskrift for Samfunnsforskning 5/6, 1977, pp. 404-406. 